\title{
ROS1 Gene Inversion
}

National Cancer Institute

\section{Source}

National Cancer Institute. ROS1 Gene Inversion. NCI Thesaurus. Code C148100.

A genetic rearrangement that refers to any inversion involving the ROS1 gene. 